\title{
Implementation of the Uninhabitable House Program in Bandarharjo Village, Semarang City
}

\author{
Endang Larasati ${ }^{1 *}$, Tri Yuniningsih ${ }^{2}$, Nina Widowati ${ }^{3}$, and Veronika Yacera Br. Sagala ${ }^{4}$ \\ \{larasati57@ymail.com ${ }^{1}$, ibutriyuniningsih@gmail.com ${ }^{2}$, ninawidowati.fisip@gmail.com ${ }^{3}$, \\ veronika@gmail.com ${ }^{4}$ \}
1,2,3 Department of Public Administration, Faculty of Social and Political Sciences, Universitas Diponegoro, Semarang - Indonesia
${ }^{4}$ Student of Public Administration, Faculty of Social and Political Sciences, Universitas Diponegoro, Semarang - Indonesia

\begin{abstract}
The Uninhabitable House Program is a program that focuses on improving the quality of houses to be liveable and alleviating slums. The purposes of this study is to describe the implementation of the rehabilitation of uninhabitable homes in Bandarharjo, Semarang City and to determine the supporting and inhibiting factors that occur in the implementation of the program. The study was conducted with a qualitative method with a descriptive approach, conducting interviews with selected informants based on the criterion-based selection technique. The results showed that the Rehabilitation Program for Non-Occupable Homes in Bandarharjo Village had been implemented but had not been implemented to the maximum, this was evidenced by the lack of achievement of objectives and the lack of fulfillment of the set targets. The inhibiting factor in the implementation of this program is the lack of human and financial resources in implementing the program. Suggestions from researchers are to increase cooperation with other slum programs, maximize program planning and synchronize data between the implementor's archive and data accessed by the public, conduct special training for implementers and increase collaboration with the private sector.
\end{abstract}

Keywords: Implementation, Program, Unhabitable House, Bandarharjo

\section{Introduction}

Housing and settlements are one of the most important basic needs for every human being. Housing and settlement development will make a major contribution to improving the welfare and poverty alleviation, it is caused by a housing development can encourage the growth of the region, regional economic growth, support social development of culture and provide a multiplier effect on other sectors such as p enciptaan employment, both directly and indirect. Some of the problems related to slum settlements are also increasing, including inadequate sanitation, poor hygiene practices, overcrowding and contaminated water, all of which can create unsanitary conditions. In addition, poor families with low levels of education tend to practice poor hygiene, which contributes to the spread of disease and increases health risks to children.

Based on data Kement e rian People's Public Works and Housing in 2012, in Indonesia 
there are slums and Semarang in the top 10 cities with slums in Indonesia. The Semarang City Government in this case determines the location of slum housing and settlements through the issuance of the Semarang Mayor's Decree Number: 050/801/2014 concerning the Determination of the Location of the Housing Environment and Slum Settlements of Semarang City. The Mayor of Semarang through this decree has designated 62 urban villages from 15 districts with a total area of 415,83 hectares. Based on the decree, the location of the most slum is in North Semarang District with a slum percentage of $\mathbf{1 3 . 8 7}$ Ha. which is the reason for the authors to determine the research locus.

DG Human Settlements has three patterns penang an early slum, one of which is the restoration of which would have the author in researching handling of slums with restoration patterns in Semarang. Handling pattern in terms of restoration based on Article 27 paragraph (2) letter e "in case the location has mild slum with legal land status, then the pattern of handling that will be carried out is restoration". Restoration is carried out to repair and / or rebuild slum housing and slum settlements into housing and habitable settlements. Restoration is an activity to repair houses, infrastructure, facilities and / or public utilities to restore their original function.

Through this restoration scheme, the Ministry of Public Works and Public Housing (PUPR) is carrying out the construction of self-help housing aimed at low-income people (MBR) through the National Million House Development Program. This program has a legal umbrella, namely Government Regulation Number 14 of 2016 concerning Implementation of Housing and Settlement Areas and Regulation of the Minister of Public Works and Public Housing Number 02 / PRT / M / 2016 concerning Quality Improvement of Slum Housing and Slum Settlements . The government divides the fulfillment of self- help houses into two categories, namely the construction of new independent houses (PBRS) and the improvement of the quality of uninhabitable houses (PKRS RTLH). The Central Bureau of Statistics (BPS) recorded that in 2015 the number of RTLHs in Indonesia was 2.51 million units, with details of 2.18 million prone to habitability and 0.33 million as unfit for habitation. Based on the PUPR e-RTLH data, it can be seen that Semarang City is one of 6 cities in Central Java Province with the second highest number of RTLHs after Pelakongan City with 5,296 RTLH data and 74,684 houses with incomplete data.

As a form of increasing welfare and reducing slum areas, the Semarang City Government is carrying out RTLH Rehabilitation. North Semarang Subdistrict, which is the location that has been designated as the most slum location, consists of nine sub-districts that have uninhabitable houses. Based on data from e-RTLH PUPR, Bandarharjo Village is a sub-district with the highest percentage of unfit for habitation houses, namely 162 houses. In this case, the writer chose Bandarharjo Village as the research locus in North Semarang District, Semarang City. Semarang City in the Rehabilitation of Unfit for Living Houses has Mayor Regulation Number 13A of 2017 concerning Guidelines for Implementing the Rehabilitation of Unfit for Living Houses in Semarang City . 
Various regions in Indonesia have implemented the Uninhabitable Housing Rehabilitation Program for low-income people in order to have a more decent housing. Research on RTLH Rehabilitation in Madiun Regency conducted by Tri Wahyuningrum and Indah Prabawati explained that there is a regulation that has only been passed after 4 years of the program, which is a guideline for program implementation. The existence of the RTLH Rehabilitation program in Madiun District did not achieve its policy objectives because there were wrong targets and dissatisfaction with beneficiaries. Rehabilitation program effectiveness RTLH in Madison County in the 4 th year running is not implemented effectively because only terseles aikan 48,7 $\%$.

In contrast to the research of RTLH Rehabilitation in Karimun Regency by Zalmi Hidayat which shows that the program is running well because it is running as expected, but there are inhibiting factors for program implementation, namely Human Resources which are less qualified and require technical guidance from officers who send HR for implementation. programs, and the lack of community awareness due to the lack of community participation in realizing decent housing.

Another study by Lawuning Nastiti also states that the implementation of the RTLH Rehabilitation Program in Magetan Regency has been carried out well but has not been fully achieved. This is due to the lack of even distribution of the budget in each village because the governing regulations do not determine the maximum limit of assistance for each village, so there are differences in the budget that each village gets.

The implementation of Belitung Regency by Bambang Winarno is also carried out well by making efforts to accelerate the program by creating a Gold Safety Program (One Billion for Each District Towards Effective, Even, Fair and Harmonious Development. In the implementation of this program there is no program audit so that it has the potential to occur. fraud or deviation related to the implementation of administrative or technical goods.

The existence of irregularities in the program also occurred in Kota Samarinda which was examined by Ibnu Abbas, where there were deviations due to construction carried out not in accordance with predetermined specifications or reducing specifications for the adequacy of building safety and health adequacy in the Minimum Service Standards (SPM) Permenpera 22 of 2008 about livable homes. So that the RTLH Rehabilitation program in Kota Samari did not work well.

The conclusions from previous research prove that the Unfit for Living Rehabilitation Program has been implemented in various regions in Indonesia. However, not all regions have been able to implement the program well, because there are still many inaccuracies in the implementation of the program, so that the program has not been implemented optimally.

Home Rehabilitation Program Implementation Research Not Livable will located on Bandarharjo village, Semarang, and will use these indicators as a measure of the accuracy of the implementation of the policy's success. Researchers will also try to see the factors supporting and inhibiting the implementation of the Rehabilitation Program for Unfit for Living.

Based on the above background, the author wants to carry out in-depth research to find out more about how the Implementation of the Unfit Home Ilitation Rehab Program in Bandarharjo Village, Semarang City. The formulation of the problem in this study are: 
a. How is the Implementation of the Rehabilitation of Uninhabitable Houses as Management of Slum Areas in Bandarharjo Village?

b. What kah supporting factors and obstacles in the implementation of the Rehabilitation Program Not Livable house in the village of Bandarharjo?

\subsection{Literature Review}

\section{Public Policy}

\section{Definition of Public Policy}

Public Policy according to Thomas R. Dye as quoted by in his book says that the definition of Public Policy is whatever governments choose to do or not to do. The policy in question is whatever the government does or does not do. Public Policy, which is meant by the definition of Dye, means that the policy is carried out by the government and the government has the right to make a decision to do or not to do the policy. Besides Dye, Carl J. Federick as quoted by Taufiqurokhman defines public policy as a series of actions / activities proposed by a person, group, or government in a certain environment where there are obstacles (difficulties) and opportunities for implementing the said policy proposal in order to achieve certain goals. This understanding shows that the implementation of a policy is the most important part rather than just proposing without action.

\section{Public Policy Stages}

The process of making public policy is a complex process because it involves many processes and variables that must be studied. Following are the stages in public policy according to [1] Build perceptions among stakeholders that a phenomenon is really considered a problem. Because it could be a symptom by a certain group of people as a problem, but by some other communities or the political elite it is not considered a problem;

1. Create problem boundaries;

Mobilize support so that the issue can be added to the government's agenda. Mobilize this support can be done by way of organizing groups in society, political forces, publicity through the mass media, and so on

\section{Policy Implementation}

Meter and Horn as quoted by [2] define policy implementation as actions taken by the government and the private sector, both individually and in groups of actions taken by the government or private, both individually and in groups intended to achieve goals as formulated in the policy.

According to Ripley and Franklin, implementation is what happens after a law is enacted that provides program authority, policy, benefits, or some kind of tangible output . The term implementation refers to a number of activities that follow a statement of intent about 
program objectives and desired results by government officials. Implementation includes actions (without actions) by various actors, especially bureaucrats, which are intended to make the program run [3]

According to [4] in Haedar Akib states that the policy implementation stage is in a different position, but in principle public policy is always followed up with policy implementation. Implementation is considered to be the main form and a very decisive stage in the policy process. Objectives The implementation of policies is formulated into specific programs of action and projects that are designed and financed. The program is implemented according to plan. The implementation of policies or programs is largely influenced by the content of the policy and the context of implementation.

Overall policy implementation is evaluated by way of measuring the outcomes of the program based on the policy objectives. The output of the program is seen through its impact on the intended targets both individuals and groups as well as the community. The output of policy implementation is change and acceptance of changes by the target group

\section{Policy Implementation Model}

According to George Edwards III in [3], Edward argues that there are 4 (four ) variables determining the success of policy implementation.

1. Communication

Communication regarding how policies are communicated to the organization and / or the public, the availability of resources to implement the policies, the attitudes and responses of the parties involved, and how the organizational structure of implementing the policies. There are three indicators that can be used in measuring the success of communication variables, namely: Transmission, Clarity, Consistency.

2. Resource

Resources relate to the availability of supporting resources, especially human resources. This is related to the ability of public policy implementers to carry out policies effectively. There are two resources that are important in policy implementation, namely human resources and financial resources.

3. Disposition (attitude of executor)

The attitude of policy implementers has important consequences for implementation to run effectively. Policy implementers must be able to work with good commitment, honesty and responsibility. The tendency that many occur affects the inhibition of implementation, such as the influence of interest groups, the existence of political reasons for the appointment of officials, causing obstacles to the implementation of policies.

4. Bureaucratic Structure

The bureaucratic structure relates to the suitability of the bureaucratic organization that organizes the implementation of public policies. The aspect used is the Standard Operating Procedures (SOP). The function of this SOP is to become a guideline for every implementor in action. If the organizational structure is too long it will tend to weaken supervision and lead to red-tape, namely bureaucratic and complex procedures, which in turn cause the organization to be inflexible. 


\section{Accuracy of Implementation}

A policy implementation is often not properly implemented, so that the goals and benefits against the target cannot be given maximally. Riant Nugroho has basic principles in the implementation of public policies, namely five accuracy of implementation [5]

1. The accuracy of the policy, this policy is assessed to what extent the policy can solve the problem to be solved. The accuracy of the policy looks at how the policy has been tampered with, whether it is in accordance with the problem to be solved and whether the policy is made by an institution that has the authority according to the character of the policy.

2. Accuracy of implementation, this is related to policy implementation actors, which as is known not only the government but there are three implementing agencies, namely government, cooperation between government, public / private sector, or privatized policies which have their respective roles according to with the urgentitas and types of policies.

3. The accuracy of the target, in this case is related to whether the target is in accordance with what was planned. Then is the target in a state ready to intervene, and whether the policy implementation is new or updates the previous policy implementation.

4. Environmental accuracy, in policy implementation there is an environment where there is an interaction between the policy making and implementing institutions, and an external environment outside the organization consisting of public perceptions, such as the mass media, interest groups and certain individuals who have important and strategic roles in interpreting policies and its implementation.

5. Process accuracy. Policy implementation consists of three processes, namely: first, policy acceptance. This means that the public's understanding of policy is the rule of the game for managing the future. For policy implementers, they must understand that policies should be implemented properly. Second, policy adoption. Policies must be approved by the public and implementors understand the policies should be implemented properly. Third, strategic readiness. The public must be ready to participate in policy implementation and bureaucrats are ready to become the main implementers who are responsible for implementing policies

\subsection{Housing and Settlement Areas}

A residential area is part of the environment outside a protected area, either in the form of an urban or a rural area, which functions as a residential environment or a residential area and a place for activities that support life and livelihood (Law No.1 of 2011).

The definition of a slum is a settlement that is not suitable for human habitation Rindarjono, Families who live in slum areas are usually low-income people (MBR), that is, people who have limited purchasing power so they need government support to acquire a house. The characteristics of slum settlements in Rindarjono include :

1. High population density of more than 1,250 million per hectare;

2. The building density is also quite high, reaching 250 or more houses per hectare;

3. Small building sizes between $25 \mathrm{~m}^{2}$ or less;

4. Irregular layout;

5. Poor sanitation;

6. Poor building quality; 
7. Slum settlements are usually associated with industrial areas, around water bodies, along railways , around central areas of activity.

\subsection{Rehabilitation of Uninhabitable Houses}

Unfit for habitation is a dwelling or place to live that is not suitable for habitation because it does not meet the housing requirements both technically and non- technically. Unfit for habitation is closely related to slum settlements because slum areas are clearly depicted community houses that are unfit for habitation. The criteria for unfit for habitation based on the Mayor of Semarang Regulation Number 13A of 2017 concerning Guidelines for the Implementation of Rehabilitation of Unfit for Living in Semarang City states that the criteria for livable houses are as follows:

a) The floor area of the house is less than $9 \mathrm{~m} 2$ (nine square meters) per person; The walls of the house are damaged and / or made of materials that are not permanent and easily damaged;

b) Roofs are damaged or made of perishable and perishable materials;

c) The floor of a house is made of earth or other material but is in a damaged condition so that it is dangerous for the health of the occupants;

d) Do not have bathing and washing toilet facilities;

e) The condition of the foundation, column and beam does not meet the safety aspects of the building;

f) The condition of the house in general does not meet the criteria for a healthy house;

g) Houses are damaged and uninhabitable due to fire / other natural disasters.

\section{Methodology}

The research methodology chosen by the writer is descriptive qualitative research methodology. This research was conducted in Bandarharjo Village, North Semarang District, Semarang City. The data sources used are primary data from interviews with informants and secondary data from literature studies, documents, government reports and so on. Determination of research informants using purposive technique. Collecting research data using interviews, documentation and literature study. Data analysis includes several stages, namely data reduction, data presentation and drawing conclusions. The technique of checking the validity of the data in this study is by using triangulation.

\section{Finding and Discussion}

\section{a. Implementation of the Rehabilitation Program for Unfit for Living in Kelurahan Bandarharjo, Semarang City}

\section{Accuracy of Policy}

In this study, the phenomenon can be seen from how the implementation of policies that have been implemented. Program Rehabilitation R ome Not Livable is a program aimed at helping poor communities to improve the quality of homes uninhabitable become feasible and 
uninhabited, and unt uk eradicate the slums.

Based on the research conducted by the author, the implementation of the Rehabilitation Program for Unfit for Living in Semarang City has been implemented since 2011 and for Bandarharjo Village, the Rehabilitation Program for Unfit for Living Houses was only implemented in 2017. Achievement of the objectives of the Program in this case is to help the poor to improve It can be said that the quality of houses has been achieved even though it has not been completely implemented, but it cannot be said that it can be said to alleviate slum areas only through this program. The total slum area included in the Decree of the Mayor of Semarang Number 050/801/2014 concerning the Determination of the Location of the Housing Environment and Slum Settlements of Semarang City is $33.44 \mathrm{Ha}$ in the Bandarharjo Village. The implementation of the Rehabilitation of Unfit for Living Houses uses a Mayor's Decree to implement the program, then in 2017 to strengthen program implementation, the Semarang City Government issued a regulation that is Semarang Mayor Regulation Number 13A of 2017 concerning Guidelines for Implementing the Rehabilitation of Unfit for Living Houses in Semarang City. The regulations governing the sources of funds used for program implementation refer to the Mayor's Regulation and the Minister of Public Works and Public Housing.

The legal basis for this program is not yet fully known by the implementation team in the field. Based on the results of the study authors in the field, the implementation team Pokmas only act as executor in the field and knowledge will be a legal basis which $\mathrm{m}$ engatur program is only known by the Department of Housing and Settlement Region.

The accuracy of the policy for the Rehabilitation of Unfit for Living Houses when viewed from the first objective, namely to help the poor to improve the quality of their houses is good enough, but if viewed from the second objective, namely alleviating slum areas, it is still not right because the slum parameter does not only cover housing, but development. infrastructure, fire extinguishers, and other requirements also support the reduction of slum areas if development can be carried out. Slum reduction must collaborate with other programs to reduce slum areas to a large extent. Based on the indicators of policy accuracy, it can be concluded that the Rehabilitation of Unfit for Living Houses in Bandarharjo Village has been carried out well but has not been optimal.

\section{Executor Accuracy}

The accuracy of the implementers in implementing a policy is also very important, because implementation requires the right implementing actors so that a policy can be implemented effectively. Planning for the Rehabilitation of Unworthy Houses in Semarang City comes from the Semarang City Government, then after planning, RTLH data collection begins, followed by physical implementation carried out by the Department of Mahan Peru and Residential Areas.

The Housing and Settlement Area Office of the City of Semarang, in terms of carrying out rehabilitation, involves Facilitators in the field to facilitate Pokmas. The efforts made by Disperkim were RTLH data collection and socialization. After data collection is carried out, verification will be carried out directly in the field to ensure that the required data is correct and appropriate, because there are still several houses whose land is illegal, so that when verification has been carried out, it will be feedback again to be re-verified and determined by letter Decision.

In its implementation, the Rehabilitation of Unfit Houses Program system is self-managed in which the beneficiaries / assistance must have the autonomy to assist the government so that the implementation of the Rehabilitation of Unworthy Houses is more effective. The kelurahan should also be aware of this program and cooperate with the Semarang City Housing and 
Settlement Office.

Other parties who are also involved in the Program are the private sector which is also known as CSR ( Corporate Social Responsibility). CSR has also been part of the Rehabilitation Program for Unfit for Living Houses in Semarang City. So far for CSR that has participated in implementing the program are Bank Jateng and PT. Marimas. The CSR party will verify the data that has been prepared by the Housing and Settlement Areas, then determine which ones will be assisted through CSR.

The executor's accuracy in the Unfit for Living Rehabilitation Program is right with the Housing and Settlement Areas Office which is the main control holder and is accompanied by other parties as the implementing team, in this case the Implementing Accuracy indicator can be concluded that the City Housing and Settlement Area Service Semarang and the ranks of implementers, both the accompanying facilitators and Pokmas in the Rehabilitation of Unfit for Living Houses, have carried out their duties well.

\section{Target Accuracy}

Target accuracy is related to the targets set by the implementor in planning. The success of the policy can be seen from how much the target has been achieved with the realization of the policy. Based on the research conducted, the program's target is correct, namely for the poor and / or the poor. Based on the data in table 4.1, it can be seen that the number of RTLHs in Semarang City continues to decline, this means that the Housing and Settlement Areas of Semarang City have done their job well in handling Unfit Houses. However, the realization from year to year was different and there was an unstable realization. For example, 2018 and 2020 were the years where the least realization was achieved in Semarang City. For 2016, there was no change in the number of uninhabitable houses because 2016 was a transitional period so there was no rehabilitation of unfit for habitation.

The realization of the overall Rehabilitation of Uninhabitable Houses in Semarang City will be described in the following table :

Table 4.1 Realization of Rehabilitation RTLH Semarang

\begin{tabular}{cccc}
\hline \multirow{2}{*}{ Year } & \multicolumn{2}{c}{ Number } & of \\
& RTLH & Realization \\
& for Semarang City & \\
\hline 2015 & 14254 & 2603 \\
2016 & 11651 & 0 \\
2017 & 11651 & 1162 \\
2018 & 10489 & 962 \\
2019 & 9527 & 1687 \\
2020 & 7840 & 978 \\
2021 & 6862 & - \\
\hline
\end{tabular}

Source: Semarang City Housing Office and Settlement Area 
Results from the study showed $t$ arget that has been set has not been achieved to the maximum because there are targets were achieved and not achieved. Basically, the targets that have been set in the implementation of R TLH Rehabilitation are quite a lot. The target set through the APBD before 2020 is 1,000 units, but by 2020 it will be 780 units.

There are various reasons why the target set cannot be realized. The first target that cannot be achieved is because the budget does not allow the completion of a certain number of targets in a predetermined year, especially for houses that do not decrease every year and continue to grow. The growth of houses, which could be in the next two years, is still quite good, but two years after that it is not feasible due to various factors. The budget is one of the most important factors in achieving the target, including for realization in 2020. The initial target of 1,000 units will then become 780 units in 2020 following the number that has been released from the center or the PUPR Ministry due to budget calculations and adjustments with Rehabilitation. The RTLH that will be carried out can only be targeted. Meanwhile, those who go through DAK must be stopped because of the funds allocated to Covid-19.

Apart from the budget, the target for implementing the RTLH could not be achieved due to differences in conditions in the first and second stages during the survey in the field. The discrepancy referred to is a change in the eligibility of the house during the first and second surveys, then the heirs are not in the house surveyed, the occupants of the house have died or moved house.

Based on the research that has been done, the data that has been received regarding the RTLH Rehabilitation in the Bandarharjo Village are not synchronized properly. This is due to the difference between the data from the given actor actors. The data comparison will be illustrated in the following table:

Table 4. 2 Realization of RTLH Rehabilitation Kel . Bandarharjo

\begin{tabular}{|c|c|c|c|c|}
\hline & 2017 & 2018 & 2019 & 2020 \\
\hline $\begin{array}{l}\text { Housing and } \\
\text { Settlement } \\
\text { Area Service }\end{array}$ & 20 & 10 & 36 & 10 \\
\hline $\begin{array}{l}\text { Bandarharjo } \\
\text { Village }\end{array}$ & 10 & 20 & 28 & $\begin{array}{c}\text { Not } \\
\text { running } \\
\text { yet }\end{array}$ \\
\hline $\begin{array}{l}\text { Pokmas } \\
\text { RTLH } \\
\text { Bandarharjo }\end{array}$ & 20 & 4 & 36 & $\begin{array}{c}\text { Not } \\
\text { running } \\
\text { yet }\end{array}$ \\
\hline
\end{tabular}

Source : The results of the interview were processed by the author on May 13, 2020

Based on the data in table 4.2, there are differences in RTLH data in Bandarharjo Village. The existence of data that is not synchronous causes questions to arise regarding the realization of the Rehabilitation of Unfit Houses in Bandarharjo Village.

Rehabilitation of unfit for habitation in Bandarharjo Village is carried out with a maximum target of 12-14 days with several stages. The accuracy of the target, in this case it is known that the target has been running according to the target implementation time, which is 12-14 days and is proven through the data that has been displayed. Even so, from the overall target set, the 
RTLH rehabilitation has not been implemented optimally, because the number of targets per year that has been set has not been fully achieved. Data synchronization between implementers is still not good. So it can be concluded that the accuracy of the target in the implementation of the Rehabilitation Program for Unfit for Living Houses in Bandarharjo Village is not optimal both in the implementation and the data on the results of its implementation.

\section{Environmental Appropriateness}

The implementation of the Rehabilitation Program for Unfit for Living in Houses must also be seen in terms of environmental accuracy. The environment within the organization or outside the organization is also related to public perception. The Housing and Settlement Area Office of Semarang City runs the Rehabilitation Program for Unfit for Living in Semarang City. With this program, Disperkim appointed a Consultant named Field Facilitator Staff who also participated in supervising and assisting the rehabilitation of RTLH in the field.

Environmental accuracy in the RTLH Rehabilitation Program can be said to be good enough. The implementation of the program so far in the form of community acceptance has received very good enthusiasm from the community and has had quite a good impact. Social impacts such as getting a more decent house in accordance with health standards and being helped by this program. Apart from this, there were responses from political elites which also led to pros and cons. Regarding the implementation of the political elite program, there are still those who leave names that need assistance or try to find names for this program through the assistance that will be provided, but the commitment from Disperkim and Facilitators can straighten and carry out their duties as well as possible, not affected by interventions in the environment external.

Based on this, the accuracy of the environment can be concluded that it is going well, because the commitment of the implementer is still good, and the interventions that are not in accordance with the stipulated

rules do not interfere with the implementation of the Rehabilitation Program for Unfit for Living Houses.

\section{Process Accuracy}

The successful implementation of the Rehabilitation Program for Unfit for Living in Bandarharjo is also seen in terms of the accuracy of the process as seen from how information is distributed and the efforts made by implementing actors as well as seeing problems that arise in the field in implementing this program. The procedural steps taken by the Housing and Settlement Area Office refer to the Guidelines for the Implementation of Rehabilitation of Unfit for Living Houses in the City of Semarang through Semarang Mayor Regulation Number 13A of 2017. The regulation states that the implementation of the program prioritizes the exploration of the potential for community self-help which can be in the form of supporting or supporting materials, home building materials and so on. But for self-help itself, the community has not been fully able to be self-reliant and have the initiative to be self -supporting . Ego society in this case also be problems where there are still people with a request that is not in accordance with the budget budgeted.

There are reports that come from various parties that are not yet certain the truth is also still frequently occurring which raises problems in program implementation. Reports regarding cuts in aid costs, reports of non-conformity requests submitted to the implementation of 
RLTH rehabilitation, and requests that are outside the stipulated plan. The existing reports were received by the Disperkim, Facilitators and Pokmas RTLH Bandarharjo in particular to be immediately followed up if there were reports or problems in the field. In order for the implementation process to continue running well, checking is carried out in the field and following up directly on the reporting party or the recipient of assistance regarding the problem being complained of. Approach by rectifying problems that arise in society. If the program is to be implemented, Disperkim usually provides a statement letter signed by the beneficiary so that from the implementor side and the beneficiaries agree to agree on the implementation of the program in the beneficiary's house.

The implementation of the Rehabilitation of Unfit for Living in this case is carried out by monitoring so that the program can run well. Monitoring carried out by Disperkim who is also assisted by field staff also involves field facilitators in terms of supervising. Checks and reports between implementing actors in the Kelurahan are confirmed to be complete and there is no problem and each implementor or aid recipient has acc. There is a joint calculation and handover between implementing actors and aid recipients to reduce unwanted things.

The monitoring system carried out in the RTLH Rehabilitation program in Bandarharjo Village is to ensure that the administration is in order and that there is delivery to beneficiaries to maintain the condition of the house both outside and inside. The Pokmas party then provides a memorandum of expenditure that has been compiled in which the field facilitators will list the purchase plan and report on the use of funds to be deposited to the Disperkim, and will be checked by the BPK whether everything is not a problem in terms of implementation from the beginning to the end of the program

Based on this, it can be concluded that the Accuracy of the Process has gone well, because the verification process was carried out from the start, ascertained the materials used, followed up the reports that occurred until the report was completed, carried out periodic monitoring and made sure all processes were on target and in accordance with the rules has been established.

\section{b. Supporting and Inhibiting Factors for Implementation of the Rehabilitation Program for Unfit for Living in Bandarharjo Urban Village, Semarang City}

\section{Communication}

The implementation of a policy must have a form of good coordination between program implementers and recipients. The delivery of information on a policy to policy recipients must be easy to understand in order for the information to be provided to run effectively. Based on the results of the research, it shows that the communication in the socialization carried out has been running effectively because it has been understood by the recipients of the policy so that this program can run without being hindered by the existing coordination. The existence of effective communication in conveying information about program implementation is a supporting factor in program implementation where the community can accept the implementation of the RTLH Rehabilitation Program.

\section{Resources}

The implementation of the policy on Rehabilitation of Unfit for Living Houses, of course, 
requires appropriate human and financial resources to implement it. HR resources can be an inhibiting and supporting factor in the implementation of the RTLH Rehabilitation Program. The number of human resources used by Disperkim in implementing the RTLH program has quite influenced the program implementation. There was a shortage of human resources in carrying out field surveys which made it overwhelming, so that the Office recruited non ASN to help with programimplementation, which was also attended by consultants as supervisors and field surveys.

The implementation of the RTLH Rehabilitation program basically does not have specific qualification standards for masons who are selected to run the program, the most important thing is to have experience in the field and understand buildings. The selection of masons is also important in supporting the running of the program, because a budget that is not too large can hamper the program if it is unable to find craftsmen who want to do rehab on a low budget. The matter regarding the selection of craftsmen who are competent in their fields is also a supporting factor if competent is also committed and can become an obstacle to the program if it does not work properly. Apart from human resources, financial resources are also a supporting and inhibiting factor in the implementation of the RTLH Rehabilitation. The source of the budget for the Rehabilitation of Unfit for Living in Semarang City comes from the APBN, APBD and CSR or other non-binding parties Meanwhile, for Bandarharjo Urban Village, financial sources come from the State Budget and Regional Budget for the City of Semarang. These sources of funds can hinder the running of programs such as 2020 in Band Arharjo Village through the APBN (DAK) funds which have been cut to become an obstacle in implementing the Rehabilitation i RTLH program in Bandarharjo Village in 2020.

\section{Disposition (attitude of executor)}

The attitude of the implementer in implementing policy implementation can also be a supporting and inhibiting factor for policy programs. The perspective of the implementer, the attitude in overcoming obstacles or problems during implementing the program and making decisions in implementing a program can be a support or a hindrance to the program. The existence of reports or news regarding problems in the field becomes an obstacle if they cannot be addressed properly. The attitude of the implementer in this case is very necessary to take action in the problems that arise, if the attitude or action of the implementer is right then the RTLH rehabilitation can continue to run well, but if it is not handled properly it will hamper the program's progress.

One example of the attitude taken by Disperkim when there is a report regarding the problem of cutting costs in the field, the actions taken by Disperkim are to check the field and make calculations as well as coordinate with the accompanying facilitator who is the supervisor in the field and resolves the problems that occur. then finish by making a statement letter from the beneficiary regarding the problems that occur.

The existence of problems in Bandarharjo Village, the attitude taken by the implementing actor was to approach the community, notify and be given directions so that the community would not be confused or other things would happen which could hinder the RTLH Rehabilitation in Bandarharjo Village. In addition to that there are difficulties in conducting field surveys when verification is going to be carried out, there are still people who do not want to be honest from the start whether they have received assistance or not, this is certainly an obstacle if the implementer does not immediately take action to reassure and seek information from people. around. When the information obtained is that the person in the survey has received 
assistance but the origin of the assistance is not yet known, the action of the implementing actor is to trace where the assistance is received as soon as possible so that they can carry out RTLH rehabilitation immediately.

Obstacles in RTLH Rehabilitation are certainly inhibiting factors that must be overcome properly. The complexity of the constraints experienced by implementing actors both in the implementation of RTLH Rehabilitation throughout Semarang City or especially in Bandarharjo Village is quite a lot. Constraints are obtained assortment, there are obstacles that come from funding sources programs are still lacking, it is derived from the people, as beneficiaries in terms of both lack of initiative in self-sufficient, the lack of cooperation by the executive actors, and their stages of funding per terms which range disbursement of budget d natural period also become an obstacle of different programs for community groups should seek to obtain material tombokan before funds RTLH down. Based on this, it can be concluded that the factor of the implementer's attitude is not an obstacle in this program, because the attitude taken by the implementor in dealing with various problems in the field has been resolved properly.

\section{Bureaucratic Structure}

Policy implementation is often hampered by the inefficiency of the bureaucratic structure. The implementer basically has to know what to do and be willing to do it well. S structures are at a less efficient bureaucracy can usually be handled by making the Standard Operating Procedure for making tasks more structured. The RTLH Rehabilitation in Semarang City already has Guidelines, namely Mayor Regulation Number 13A of 2017, but for teams in the field such as Pokmas or masons who work on them, they do not have Standard Operational Procedures, only work according to experience. The hope is that in the absence of Standard Operating Procedures, the field team will still be able to maintain commitments and can work well so as not to cause obstacles. Based on this, it can be concluded that the bureaucratic structure factor is not an obstacle in the Rehabilitation of Unworthy Houses in Bandarharjo Village, although only the Housing and Settlement Services Office has SOPs , because field implementers can still carry out their duties properly.

\section{Conclusion}

Based on the results of data presentation and discussion of research on the Implementation of the Rehabilitation Program for Unfit for Living in the Bandarharjo Village, Semarang City , he can take the following conclusions.

The implementation of the RTLH Rehabilitation Program in Bandarharjo Village has been implemented quite well but has not been implemented optimally. This is evidenced by the 5 ( five ) indicators studied, namely 2 (two) indicators that have been implemented properly but are not yet optimal. Based on the indicators of policy accuracy, it can be concluded that the Rehabilitation of Unfit for Living Houses in Bandarharjo Village has been carried out well but has not been optimal. The accuracy of the target, in this case it is known that the target has been running according to the target implementation time, which is 12-14 days and is proven through the data that has been displayed. Even so, from the overall target set, the RTLH rehabilitation has not been implemented optimally, because the number of targets per year that has been set has not been fully achieved. 
However, there are 3 (three) indicators that are well implemented, namely the implementation accuracy of the Unfit for Housing Rehabilitation Program with the Housing and Settlement Services Office which is the main control and is accompanied by other parties as the implementation team. . K etepatan concluded neighborhood has been running well, because the implementor commitment remains good, and the interventions that are not in accordance with predetermined rules do not interfere with the implementation of the Rehabilitation Program Not Livable house. The accuracy of the process has been going well, because the verification process is carried out from the start, ensuring the materials used, following up the reports that occur until the report is complete, conducting periodic monitoring and ensuring that all processes are on target and in accordance with the established rules.

Supporting factors for the implementation of the Rehabilitation Program for Unfit for Living in Bandarharjo Village, Semarang City include: Communication in the R TLH Rehabilitation program has been going well;

The bureaucratic structure factor does not become an obstacle in the Rehabilitation of Unworthy Houses in Bandarharjo Village, although only the Housing and Settlement Services Office has SOPs , because field implementers can still carry out their duties properly; The factor of the attitude of the implementer is not an obstacle in this program, because the attitude taken by the implementer in facing various problems in the field has been resolved properly. Inhibiting factors include resources when viewed from the quantity of human resources, which is still inadequate, and financial resources are also an inhibiting factor for the program because there is still a lack of funds to achieve the specified targets.

\section{References}

[1] B. Winarno, Teori dan Proses. Yogyakarta: Kebijakan Publik, Media Pressindo, 2002.

[2] S. Suwitri, Konsep dasar kebijakan publik. Semarang: Badan Penerbit Universitas Diponegoro, 2008.

[3] B. Winarno, Kebijakan publik, teori, proses, dan studi kasus (cetakan kedua. Yogyakarta: Center of Academic Publishing Service, 2014.

[4] S. A. Wahab, Analisis kebijakan: dari formulasi ke penyusunan model-model implementasi kebijakan publik. Jakarta: Bumi Aksara, 2012.

[5] R. Nugroho, Public Policy: Theory. Management Dynamics, analysis, Convergence, and chemical policy. Jakarta: PT Elex Media Gramedia Group Komputindo Jakarta, 2014. 